DOI 10.18551/rjoas.2021-10.04

\title{
THE EFFECT OF SOUND GOVERNANCE AND PUBLIC FINANCE MANAGEMENT ON THE PERFORMANCE OF LOCAL GOVERNMENTS
}

\author{
Komang Adi Kurniawan Saputra \\ Faculty of Economics and Business, Warmadewa University, Bali, Indonesia \\ E-mail: adikurniawan@warmadewa.ac.id
}

\begin{abstract}
This study aims to examine the effect of sound governance and public finance management on the performance of local governments in Buleleng Regency, Bali, Indonesia. The government's performance in Indonesia is in the public spotlight, especially during the current Covid-19 pandemic. Public services, corruption, embezzlement of social assistance and so on occur under the pretext of humanity. This study contributes to preventing financial fraud in local governments by offering new concepts of governance and finance. This study uses a saturated sample of 39 leaders of regional apparatus organizations. The method of data collection was carried out by distributing survey questionnaires to 39 leaders of regional apparatus organizations. The data collected were analyzed by multiple linear regression method. The result is that sound governance and public finance management have a significant positive effect on local government performance. This means that both sound governance and public finance management need to be implemented in government and financial management as a breakthrough for the community's economic conditions during the Covid-19 pandemic.
\end{abstract}

\section{KEY WORDS}

Sound governance, public finance management, performance, good governance, COVID 19.

Local governments are responsible for the management and implementation of public services to citizens. Performance of Local Government Administration is a reflection of the achievement of local government performance in carrying out their duties. Based on Government Regulation number 6 of 2008, local government performance refers to the Inputs-Outputs-Outcomes model. The performance of local governments can be seen from the Performance Accountability Report of Government Agencies. The report contains accounting information related to local government finances (Safitri et al., 2018). One of the accounting functions in the public sector is reporting on the performance achievements of public sector entities. International Public Sector Accounting Standard No.1 which is a standard for presenting financial statements in the public sector states that public sector financial statements represent the financial position and financial performance of public sector entities (Nugraha, 2012).

One of the important factors in the government sector is good governance or what is known as good governance. However, along with the times and the demands of globalization, the concept of good governance applied in governance needs to be perfected (Gbegi \& Adebisi, 2015). In perfecting the concept of good governance, sound governance emerged with a much more comprehensive view.Sound Governance is governance that is covered by aspects of local traditions or innovations on how a government should be organized, according to customs, culture, and local contexts (Nahar \& Zulkeppeli, 2015). The concept of sound governance that is identical today is the simplification of the bureaucracy. Testing and reviewing sound governance in improving the performance of local governments, especially in Indonesia, is still relatively new and not deep. For example, the implementation of sound governance in the Mamminasata government of South Sulawesi Province with the dimensions of process, structure, values, management, and policies only arrived at an overview of sound governance with good research results (Firdaus, 2016).

Camay and Gordon (2002) argue when linking governance with government performance in a democratic transition situation in South Africa that the study of sound 
governance must consider the context of the public financial management system. Farazmand (2012) when conducting a study related to government governance which also discusses good governance, he suggests the dimensions of sound governance that successfully synergize with the dimensions of good governance, thus providing excellent governance quality, namely the dimensions of process, structure, cognition and values, constitution, organization and institutions, management and performance, policies, sectors, international forces or globalization, and ethics, accountability and transparency (Harrison \& Donnelly, 2011).

Studies and theories that link sound governance with government performance, especially in the concept of contingencies, are rarely found. At least these studies and theories encourage a study of the good corporate governance literature that has developed in the private sector as an inspiration for good governance and ultimately forms sound governance. It can be said that the influence of good corporate governance on performance in the private or corporate sector is almost conclusive (Saputra et al., 2019; William et al., 2013). GCG studies generally begin with a discussion of agency theory (Ekayani et al., 2020; lqbal et al., 2019). Agency theory suggests that shareholders have different interests so that it is necessary to appoint managers to carry out activities and achieve overall organizational goals. Principal wants this goal to be realized by the manager as the agent he appointed. It's just that it is often found that managers have goals other than those mandated, maybe even contradictory, so that agency problems arise. This occurs when managers have incentives to fulfill their personal interests to the detriment of broad owners. Failure to manage agency problems will result in excessive agency costs (Junita \& Abdullah, 2017; Whipple, 2018).

On the other hand, the management theory (stewardship theory) views management as a party who is trusted to act as well as possible for the public interest in general and shareholders in particular. The implication of this is that the steward (government management) will work as well as possible for the interests of the principal (society) (Jensen \& Meckling, 1976b; Rashid, 2016). However, sometimes the steward cannot play a role as expected so that stewardship problems arise such as acts of betrayal, collective identity becomes individualistic, the relationship between the steward and the principal is transitory and depends on contingencies (Davis et al., 1997; Jacobs, 2005; Jensen \& Meckling, 1976a). In dealing with agency problems and stewardship problems while achieving the expected performance, principals usually apply corporate governance. It's just that the empirical evidence of the role of corporate governance on performance is not entirely conclusive (Raharjo, 2007; Rashid, 2016).

Contingency theory implies that the best way to manage an organization, lead or make decisions is the ability to align internal and external situations (contexts) that are interdependent (contingents) to find the right strategy in order to achieve goals (Efferin \& Hopper, 2007; Naranjo-Gil \& Hartmann, 2007). The right relationship between strategy and context (external environment and organizational characteristics) has positive implications for performance. The right relationship is contained in the public financial management system (Harrison \& Donnelly, 2011). Public finance management refers to a set of laws, rules, systems and processes used by a government to mobilize revenues, allocate public funds, conduct public expenditures, and account for funds and audit results. It encompasses a broader set of functions than financial management and is usually understood as a cycle that begins with policy design and ends with external audit and evaluation. A large number of actors are involved in this cycle, to ensure it operates effectively and transparently, while maintaining accountability (Asher et al., 2015; Lawson, 2012).

Public financial management practices are considered to reduce corruption and poverty, as well as ensure the effective use of internal and external resources (Matibini, 2017; Morgner \& Chêne, 2014). PFM measurement is a non-financial measurement, tends to assess the effectiveness of regional financial management. Therefore, PFM divides nine strategic areas which are keys to the effectiveness of local financial management. The framework developed by the world bank and the Indonesian government can assess financial management (Chhetri et al., 2012; French, 2013; Sześciło, 2020). This framework is divided into nine strategic areas which are the effectiveness of financial management at the 
government level, namely: regulatory framework, planning and budgeting, cash management, procurement, accounting and reporting, internal audit, public debt and investment, asset management, and external audit and oversight (Alawattage \& Azure, 2021; Ayu \& Riani, 2015; Mbaku \& Smith, 2012).

This PFM covers all aspects related to the management, receipts, and expenditures of state or regional finances. In the whole of system approach, PFM involves all stakeholders including the community, government, and representative institutions in an effort to identify public services needed by the community (Cheruiyot et al., 2017; Goryakin et al., 2020; Kioko et al., 2011; Lahiri, 2000). However, the government has obstacles to be able to accommodate all public needs due to limited financial resources. Therefore, the government must be able to effectively allocate and manage its financial resources into development programs and activities that can encourage the realization of community welfare. Studying the PFM concept can be viewed from various perspectives. Chenhall and Langfield-Smith (1998) through cluster analysis on the priority product differentiation strategy proves that management techniques and management accounting have an effect on performance.

This study tries to prove the effect of sound governance and public finance management on performance with a different approach from previous research. First, the context of research on local government as a form of public sector organization has implications for construct adjustments for related indicators or variables, such as performance indicators, not only financial or efficiency measures but also non-financial measures such as services and staff or human resources. Second, the placement of public finance management (PFM) and sound governance which together affect performance. Previous research only conducted a survey of the dimensions of PFM in various regions in Indonesia, Africa and other Asia (Alawattage \& Azure, 2021; Bajo et al., 2017; Chhetri et al., 2012). It is hoped that by changing the form and direction of the relationship, it can prove the true relationship between sound governance and its mediating variables on performance.

\section{THEORETICAL REVIEW}

Agency theory tries to establish a formal relationship between the principal and the agent or other interested parties in the budgeting process (Darwis, 2017; Lerner et al., 2009). This theory emphasizes the design of performance measurement and rewards given so that managers behave positively or benefit the company as a whole (Yolles, 2019). The agency theory postulates do not apply to all situations. Agency theory focuses on two individuals, namely the principal and the agent (Fama, 2012; Reverte, 2009). The principal delegates responsibility for decision making to the agent. Both principals and agents are assumed to be rational economic people who are motivated solely by self-interest, but they have difficulty distinguishing rewards for preferences, trust and information. The rights and obligations of the principal and agent are explained in a mutually beneficial employment agreement (Whipple, 2018). In management accounting research, agency theory is used to identify the combination of employment contracts and information systems that will maximize the principal's benefit function, and the behavioral constraints that arise from the agent's interests. The agent theory observes the phenomenon of budget slack (difference) which is described as inefficiency or loss of income from information that is symmetrical to decisions (Henley et al., 2001; Maestrini et al., 2018). In agency theory, management accounting information is used for two purposes. First, it is used for decision making by principals and agents. And second, it is used to evaluate and share the results in accordance with the work contract that has been made and approved. This is called a performance evaluation role which can motivate agents to try their best (Dirsmith et al., 1997; Jensen, 2005).

Contingency theory is a view that is oriented towards internal needs that must be able to adapt to its environment (Langfield-Smith, 1997). Otley (1980)states that the company and its environment are like two sides of a coin that cannot be separated and are interconnected. The development of the company will be greatly influenced by changes and environmental uncertainty. Contingency theory is used to analyze the design and management accounting system so that it can be useful to produce information that is used by companies for various 
purposes, for example in formulating strategies and to win business competition (Govindarajan, 1988; Naranjo-Gil \& Hartmann, 2007). Theory of contingency is a theory that is suitable to be used in terms of studying the design, design, performance and behavior of organizations as well as studies related to strategic arrangements.

Stewardship theory was introduced as a theory based on behavior and premises (Jacobs, 2005). Stewardship theory is defined as a situation where managers do not have personal interests but are more concerned with the wishes of the principal (Davis et al., 1997). This theory is relatively new so that its theoretical contribution is less solid. Stewardship theory has psychological and sociological roots designed to explain situations in which managers are stewards and act in the interests of owners (Raharjo, 2007). In the theory of stewardship, managers will behave according to the common interest. When the interests of the steward and the owner are not the same, the steward will try to cooperate rather than oppose it, because the steward feels mutual interests and behave in accordance with the owner's behavior is a rational consideration because the steward is more concerned with efforts to achieve organizational goals (Jacobs, 2005; Morgan et al., 1996). Stewardship theory assumes a strong relationship between organizational success and owner satisfaction. Steward will protect and maximize the wealth of the organization with the company's performance, so that the utility function will be maximized. An important assumption of stewardship is that managers align goals with those of the owners. However, it does not mean that the steward does not have the necessities of life (Davis et al., 1997).

Sound governance has dimensions or components that make up a dynamic system, interact with each other, and all form a unity that takes into account internal diversity, complexity and intensity, and addresses external challenges, constraints and opportunities (Faturrahman, 2019; Firdaus, 2016; Holidin \& Handini, 2014). A process that increases the level of capacity building, innovation, creativity, and adaptive response (Farazmand, 2012; Pal, 2014; Taylor, 2003). This is a healthy characteristic of dynamic processes and structures in a sound governance system, as the system is encouraged to generate independence through its creativity and innovation in policy and administration in various fields, and is encouraged to make leaps towards capacity building and improvement of administration and self-governance. . sound governance is presented as a more comprehensive notion of governance that includes good governance and sound public administration (Andhika, 2017; Camay \& Gordon, 2002; Safitri et al., 2018). It is requires adaptability, capacity building and development, innovation in policy and management, and a sound administrative system that is dynamic, flexible, diverse in character, and solid in structure and value orientation (Farazmand, 2004; Safitri et al., 2018). Sound governance refers to a more comprehensive idea of governance, which includes good governance and reliable public administration. This of course requires adaptability, capacity building, innovation in policy and management, as well as a reliable administrative system that is dynamic, flexible, diverse in character, and solid in structure and value orientation (Safitri et al., 2017).

Public Financial Management is one of the analytical tools developed by the World Bank to obtain an accurate and comprehensive picture of financial management; and develop strategies and activities to strengthen financial management, as well as increase local financial management capacity (Asian Development Bank, 2018; Lawson, 2012). It becomes important if there are aspects of financial management that have not been fulfilled, for improvement and strengthening, and for this reason, PFM analysis is needed to capture the capacity of each district/city in financial management (Asher et al., 2015; Matibini, 2017). Public Financial Management Analysis aims to determine the capacity of regional financial management (Morgner \& Chêne, 2014; Sześciło, 2020). The existence of public financial management by the government is very important considering the level of public welfare in Indonesia is still low, such as there is still a lot of poverty with a low level of fulfillment of needs, corrupt practices that occur in every field of government,Nationalincomeunequal distribution, low economic growth, and various other budget irregularities (Alawattage \& Azure, 2021; Ayu \& Riani, 2015; Chhetri et al., 2012). This could be due to a lack of a deeper understanding of public financial management (Lahiri, 2000; Lengkong et al., 2018; Mbaku \& Smith, 2012). 


\section{METHODS OF RESEARCH}

The research design used in this study is a survey method. Survey research design is a research design with the aim of conducting a careful and thorough examination of an object of research based on a certain situation or condition by looking at its suitability with certain statements or values which are followed and observed carefully and thoroughly. Research on the impact of sound governance and public finance management on the performance of local governments will conduct a survey to the leaders of regional organizations in Buleleng Regency as respondents. The population of this research is the leaders of regional apparatus organizations in Buleleng Regency, totaling 39 people. The selection of regional organizations is expected to increase the rate of return of the questionnaire from respondents' answers and the questionnaire can be returned quickly, thus minimizing the occurrence of response bias. The sample used in this study was a saturated sample, meaning that the entire population was also used as a sample, namely 39 people.

This study uses primary data which is a source of research data obtained directly from the source. The method of data collection in this study is the technique of collecting questionnaires. The total number of questionnaires sent by the entire sample was 39 questionnaires according to the specified number of samples. This study uses personally administered questionnaires, which means that researchers can deal directly with respondents and provide necessary explanations about the questionnaire and can be collected immediately after being answered by the respondent.Prior to data analysis, the instrument was tested for validity and reliability as well as classical assumption test, multicollinearity test, heteroscedasticity test and normality test. Meanwhile, to examine the relationship between sound governance and public finance management variables on the performance of local governments using multiple linear regression with the OLS (Ordinary Least Square) model.

\section{RESULTS AND DISCUSSION}

The results of the normality test with the One Sample Kolmogorov Smirnov Test showed the Asymp.Sig (2-tailed) result of 0.336 which was higher than 0.05 so that the data was said to be normally distributed. The results of the calculation of the tolerance value show that all independent variables have a tolerance value, each of which is 0.992 greater than 0.10 . The results of the calculation of the VIF value also show that all independent variables have a VIF value of $<10$, with each number being 1.00 , so it can be concluded that there are no symptoms of multicollinearity between the independent variables. Meanwhile, the results of the heteroscedasticity test show that all variables are not significant at 0.05 so it can be concluded that there is no heteroscedasticity.

Table 1 - Results of hypothesis testing with multiple linear regression analysis

\begin{tabular}{|c|c|c|c|c|c|c|}
\hline \multicolumn{7}{|c|}{ Coefficients $^{a}$} \\
\hline \multirow{2}{*}{\multicolumn{2}{|c|}{ Model }} & Unstan & Coefficients & Standardized Coefficients & & \\
\hline & & B & Std. Error & Beta & $\mathrm{T}$ & Sig. \\
\hline \multirow{3}{*}{1} & (Constant) & 18,553 & 9,664 & & 1920 & .065 \\
\hline & $\mathrm{X} 1$ & .192 & .041 & .626 & 4.710 & .000 \\
\hline & $\mathrm{X} 2$ & .472 & 221 & 284 & 2.137 & .042 \\
\hline
\end{tabular}

From the results of the regression analysis in the table above, the following regression equation can be arranged: $Y=18.553+0.192 X 1+0.472 X 2+$ e. Based on this value, it can be stated that the variables of sound governance and public finance management have a significant positive effect on the performance of local governments.

The spread of Covid-19 has become increasingly massive in recent weeks, including in Indonesia. The rapid development of the spread of Covid-19 has an impact on many aspects, including social and economic aspects (Sara et al., 2020). The social distancing policy and work from home recommendations taken by the Indonesian government to reduce 
the spread of Covid-19 have resulted in several sectors, including the tourism, transportation, manufacturing, finance, public services, and other sectors to reduce or temporarily stop their activities indefinitelydetermined (Mohd Noor \& Mansor, 2019). This has a huge impact on the country's economy, both on a macro and micro scale (Saputra et al., 2018). Another aggravating factor is that its distribution has reached most areas in Indonesia. Therefore, a number of policies and anticipatory measures have been taken by the government, both at the central government, provincial, district, and city governments in an effort to overcome the Covid-19 pandemic (Larasdiputra \& Saputra, 2021). The main step that has been taken by the government is the issuance of Government Regulation in Lieu of Law No. 1 of 2020 concerning State financial policy and financial system stability for handling the COVID-19 pandemic (Uğur \& Akbıyık, 2020). Broadly speaking, the Perppu discusses two things, namely the first policy on state finances and regional finances, namely regulating income, spending and financing policies. The second is the financial system stability policy which includes policies for handling financial institution problems that endanger the national economy and/or the stability of the State financial system (Sara et al., 2020).

Adequate anticipation must be followed by appropriate decision making, especially for the government to be able to minimize the negative impact on the economic sector and state finances. The implementation of the perppu can be done by rearranging the scale of spending priorities, reallocating spending, andutilization of excess budget balance, endowment funds, funds controlled by the government with certain criteria, and funds managed by the Public Service Agency (Agustini et al., 2019). The first thing that can be done by the government, both central and local, is to analyze the expenditure that has been budgeted at the beginning of the period. After that, the government must determine the priority scale by sorting the spending budget based on the level of urgency (Wiratno et al., 2017). The government can refocus on the budget, especially for the health and social sectors (Abdullah et al., 2006). This refocusing of the spending budget is also necessary because of the decline in revenue budget assumptions. In addition, the government needs to identify risks and mitigate liability risks in the context of good governance and sound governance (Holidin \& Handini, 2014; Safitri et al., 2017).

The reallocation is mainly but not limited to efforts to allocate the capital expenditure budget to operational expenditures. This is important to do because the main priority is now heading towards overcoming Covid-19 and its various domino effects (Sara \& Saputra, 2021; Sujana et al., 2020). This activity can be carried out by reducing / temporarily stopping infrastructure development activities, as well as other investment activities being reallocated for Covid-19 prevention expenditures. The government can also cut certain expenditures, such as spending on official travel, meeting spending, technical guidance, counseling, and the like to be diverted to handling Covid-19 (Camay \& Gordon, 2002; Faturrahman, 2019). Furthermore, the government can take advantage of excess budget balances, endowments, funds controlled by the government with certain criteria, and funds managed by public service agencies. Central and regional government agencies can take advantage of these funding sources in accordance with their designation for handling the impact of Covid-19 and preparing for the recovery period (Firdaus, 2016; Ridla \& Kusuma, 2016).

The concept of governance that has been applied so far has been good, but in the conditions of the COVID-19 pandemic, the demands for improving good governance are increasingly urgent, seeing the decline in public trust in government performance (Dion, 2008). This can be seen when there is a delay in the distribution of aid, overlapping regulations for the recipient community, public services, and so on. Improving good governance is one solution, especially in the province of Bali. The province of Bali is one of the regions that has experienced a very drastic decline in income, because it depends on the tourism sector, which is currently experiencing a decline of up to $80 \%$ due to the COVID-19 pandemic. In perfecting the concept of good governance, Sound Governance emerged with a much more comprehensive view (Lee et al., 2018; Nahar \& Zulkeppeli, 2015). Sound Governance is governance that is covered by aspects of local traditions or innovations on how a government should be organized, according to customs, culture, and local contexts (Camay \& Gordon, 2002; Nahar \& Zulkeppeli, 2015). 
The concept of sound governance that is identical today is the simplification of the bureaucracy. In this COVID-19 pandemic, the government is required to be fast, responsive and accountable (Lee et al., 2018; Nahar \& Zulkeppeli, 2015). This condition causes that sound governance is implemented so that the bureaucracy is no longer complicated, long, and convoluted (Farazmand, 2004; Pal, 2014). Sound Governance was born basically to perfect the previous concept, namely the concept of Good Governance. Good Governance has three pillars, namely Government, Private, and Community (Nugraha, 2012; Safitri et al., 2018). Meanwhile, Sound Governance has four pillars, namely Government, Private, Society, and International Actors. The concept of Sound Governance complements the previous concept which was deemed less than perfect as a result of the era of globalization which requires the government system to continue to develop (Camay \& Gordon, 2002; Firdaus, 2016). So conceptually the two concepts have a close relationship. Furthermore, the government also has a role in providing more opportunities to the public and the private sector in the implementation of development. The private sector plays the main role in development, makes the non-agricultural sector a driving force for regional economic growth, the main actor in creating jobs, and the main contributor to government and regional revenues (Camay \& Gordon, 2002; Faturrahman, 2019; Firdaus, 2016; Holidin \& Handini, 2014; Pal, 2014; Ridla \& Kusuma, 2016). The community plays the main role (not participates) in the development process, it is necessary to develop and strengthen institutions so that they are able to be independent and build networks with various parties in carrying out their production and consumption functions, as well as the need for empowerment to increase efficiency, productivity and quality of production. So it can be concluded that sound governance has an effect on government performance (Andhika, 2017; Holidin \& Handini, 2014; Nugraha, 2012).

Public financial management practices are considered to reduce corruption and poverty, as well as ensure the effective use of internal and external resources (Nyamita et al., 2015; Pimenta \& Pessoa, 2015; Porter et al., 2011). PFM measurement is a non-financial measurement, tends to assess the effectiveness of regional financial management. Therefore, PFM divides nine strategic areas which are keys to the effectiveness of local financial management. The framework developed by the world bank and the Indonesian government can assess financial management (Jaelani, 2016; Lawson, 2013; Park et al., 1996). The existence of public financial management by the government is very important considering the level of public welfare in Indonesia is still low, such as there is still a lot of poverty with a low level of fulfillment of needs, corrupt practices that occur in every field of government,National incomeunequal distribution, low economic growth, and various other budget irregularities (Jaelani, 2015; McCue, 2007; Shaikh et al., 2012). This could be due to the lack of a deeper understanding of public financial management. With the existence of public financial management can support economic growth, this means that if a country's public financial management is said to be good without defects, it is likely that outside investors will be more interested in placing their funds in a country with good management of public financial statements (David, 2014; Lin \& Yi, 2011; Poterba, 1993). With the funds from outside investors, it can drive economic growth and continue to grow. Functionally and objectively, public financial management has a lot of impact on all sectors and lines in a country (Schiavo-Campo, 2018; Ueshima, 2014). The process of making public financial reports is important and becomes a vulnerable thing if it cannot be implemented properly. The need to use a credible accounting system can help support the acceleration and proper accuracy in the financial reporting. Just like financial management in the public sector (Ford \& Quigley, 1990; Kristensen et al., 2019; Tanzi, 1999).

\section{CONCLUSION}

Based on the results of research data analysis, it can be stated that the variables of sound governance and public finance management have a significant positive effect on the performance of local governments. The government is now refocusing on the budget, especially for the health and social sectors. This budget refocusing is also necessary 
because of the declining revenue budget assumptions.In addition, the government needs to identify risks and mitigate liability risks in the context of good governance and sound governance. The current Covid-19 condition causes the government to be obliged to implement sound governance to improve good governance. Improving good governance is one solution, especially in the province of Bali. The province of Bali is one of the regions that has experienced a very drastic decline in income, because it depends on the tourism sector, which is currently experiencing a decline of up to $80 \%$ due to the COVID-19 pandemic. In perfecting the concept of good governance, Sound Governance emerged with a much more comprehensive view. And public financial management practices are considered to reduce corruption and poverty.

\section{REFERENCES}

1. Abdulllah, Syukriy, \& Halim, A. (2006). Studi atas Belanja Modal pada Anggaran Pemerintah Daerah dalam Hubungannya dengan Belanja Pemeliharaan dan Sumber Pendapatan. Jurnal Akuntansi Pemerintah, 2 (2).

2. Agustini, N. M. W., Trisnadewi, A. A. A. E., \& Saputra, K. A. K. (2019). Pengaruh Partisipasi Anggaran, Asimetri Informasi, Kualitas Sumber Daya Manusia Dan Kejelasan Sasaran Anggaran Terhadap Budgetary Slack Pada Organisasi Perangkat Daerah Kabupaten Bangli. JEMA: Journal of Economic, Management and Accounting Adpertisi, 1 (1).

3. Alawattage, C., \& Azure, J. D. C. (2021). Behind the World Bank's ringing declarations of "social accountability": Ghana's public financial management reform. Critical Perspectives on Accounting, 78 (xxxx), 1-22. https://doi.org/10.1016/j.cpa.2019.02.002.

4. Andhika, L. R. (2017). Evolusi Konsep Tata Kelola Pemerintah: Sound Governance, Dynamic Governance Dan Open Government. Jurnal Ekonomi Dan Kebijakan Publik, 8 (2), 87-102. https://doi.org/10.22212/jekp.v8i2.867.

5. Asher, M. G., Bali, A. S., \& Chang, Y. K. (2015). Public financial management in Singapore: Key characteristics and prospects. Singapore Economic Review, 60 (3). https://doi.org/10.1142/S0217590815500320.

6. Asian Development Bank. (2018). Public Financial Management Systems - Sri Lanka (Issue MAy).

7. Ayu, I., \& Riani, P. (2015). Analisa Public Finance Management. Jurnal Kajian Ekonomi Dan Keuangan Daerah, 1 (1), 20-54.

8. Bajo, A., Primorac, M., \& Runtić, D. (2017). Public Financial Management, Accountability, and Citizens' Trust. Hrvatska i Komparativna Javna Uprava, 17 (3), 389-405. https://doi.org/10.31297/hkju.17.3.3.

9. Camay, P., \& Gordon, A. J. (2002). Civil Society as Advocate of Social Change in Preand Post-transition Societies: Building Sound Governance in South Africa. ISTR Conference, 1 (July), 7-10.

10. Chenhall, R. H., \& Langfield-Smith, K. (1998). The relationship between strategic priorities, management techniques and management accounting: An empirical investigation using a systems approach. Accounting, Organizations and Society. https://doi.org/10.1016/S0361-3682 (97)00024-X.

11. Cheruiyot, P. M., Oketch, J. R., Namusonge, P. G. S., \& Sakwa, P. M. (2017). Effect of Public Financial Management Practices on Performance in Kericho County Government, Kenya: a Critical Review. International Journal of Education and Research, 5 (12), 211224. www.ijern.com.

12. Chhetri, B. B. K., Lund, J. F., \& Nielsen, O. J. (2012). The public finance potential of community forestry in Nepal. Ecological Economics, 73, 113-121. https://doi.org/10.1016/j.ecolecon.2011.09.023.

13. Darma, I. K., \& Saputra, K. A. K. (2021). Analysis Of The Potential Of Motor Vehicle Taxes And The Level Of Risk During The Covid-19 Pandemic To Increase Regional Income In Bali Province. Palarch's Journal Of Archaeology Of Egypt/Egyptology, 18 (7), 872-882. 
14. Darwis, H. (2017). Ukuran Perusahaan, Profitabilitas, Dan Financial Leverage Terhadap Pengungkapan Tanggung Jawab Sosial Perusahaan High Profile Di Bei. Jurnal Keuangan Dan Perbankan, 13 (1), 52-61.

15. David, H. N. (2014). Public Finance: A Contemporary Application of Theory to Policy.

16. Davis, J. H., Schoorman, F. D., \& Donaldson, L. (1997). Toward A Stewardship Theory Of Management. Academy of Management Review, 22 (1), 20-47.

17. Dion, M. (2008). Ethical leadership and crime prevention in the organizational setting. Journal of Financial Crime, 15 (2), 308-319. https://doi.org/10.1108/13590790810882892

18. Dirsmith, M. W., Heian, J. B., \& Covaleski, M. A. (1997). Structure and agency in an institutionalized setting: The application and social transformation of control in the big six. Accounting, Organizations and Society, 22 (1), 1-27. https://doi.org/10.1016/S0361-3682 (96)00005-0.

19. Efferin, S., \& Hopper, T. (2007). Management control, culture and ethnicity in a Chinese Indonesian company. Accounting, Organizations and Society, 32 (3), 223-262. https://doi.org/10.1016/j.aos.2006.03.009.

20. Ekayani, N. N. S., Sara, I. M., Sariani, N. K., Jayawarsa, A. A. K., \& Saputra, K. A. K. (2020). Implementation of good corporate governance and regulation of the performance of micro financial institutions in village. Journal of Advanced Research in Dynamical and Control Systems, 12 (7), 1-7. https://doi.org/10.5373/JARDCS/V12I7/20201977.

21. Fama, E. (2012). Agency problems and the theory of the firm. The Economic Nature of the Firm: A Reader, Third Edition, 88 (21), 270-282. https://doi.org/10.1017/CBO9780511817410.022.

22. Farazmand, A. (2004). Globalization and Governance: A Theoretical Analysis. Sound Governance: Policy and Administrative Innovations, 330.

23. Farazmand, A. (2012). Sound Governance: Engaging Citizens through Collaborative Organizations. Public Organization Review, $12 \quad$ (3), 223-241. https://doi.org/10.1007/s11115-012-0186-7.

24. Faturrahman, B. M. (2019). Pemikiran Kritis Sound Governave Terhadap Globalisasi: Pandangan Dari Ali Farazmand. Jurnal Politik Dan Sosial Kemasyarakatan, 11 (2), 1689_ 1699. e-jurnal.unisda.ac.id.

25. Firdaus, F. (2016). Sound Governance in the Development of Mamminasata Metropolitan Areas in South Sulawesi Province. JKAP (Jurnal Kebijakan Dan Administrasi Publik), 20 (1), 1. https://doi.org/10.22146/jkap.9915.

26. Ford, J. F. G., \& Quigley, J. M. (1990). LOCAL PUBLIC FINANCE AND ECONOMIC DEVELOPMENT: The Indonesian Context. In Review of Urban \& Regional Development Studies (Vol. 2, Issue 2, pp. 139-150). https://doi.org/10.1111/j.1467940X.1990.tb00020.x.

27. French, B. (2013). The Impact of Public Financial Management Interventions on Corruption. Governance Advisor DFID-Pakistan, 12 (August), 1-29. http://www.gsdrc.org/wp-content/uploads/2016/06/The-Impact-of-PFM-Interventions-onCorruption-v7-FINAL-2.pdf.

28. Gbegi, D. O., \& Adebisi, J. F. (2015). Analysis Of Fraud Detection And Prevention Strategies In The Nigerian Public Sector. Journal of Good Governance and Sustainable Development in Africa, 2 (4), 109-128.

29. Goryakin, Y., Revill, P., Mirelman, A. J., Sweeney, R., Ochalek, J., \& Suhrcke, M. (2020). Public financial management and health service delivery: A literature review. Global Health Economics: Shaping Health Policy In Low- And Middle-Income Countries, April, 191-215. https://doi.org/10.1142/9789813272378_0007.

30. Govindarajan, V. (1988). A Contingency Approach to Strategy Implementation at the Business-Unit Level: Integrating Administrative Mechanisms with Strategy. Academy of Management Journal. https://doi.org/10.5465/256341.

31. Harrison, C., \& Donnelly, I. A. (2011). A theory of smart cities. 55th Annual Meeting of the International Society for the Systems Sciences 2011.

32. Henley, J., Cotter, M., \& White, C. (2001). exeptions to agency theory assumptions and the rise contingency employment in marketing. Marketing Management Journal, 
123-131.

33. Holidin, D., \& Handini, R. S. (2014). Sound Governance Analysis in the Innovation of Traditional Market Revitalization and Street Vendors Management. Bisnis \& Birokrasi Journal, 21 (1). https://doi.org/10.20476/jbb.v21i1.4040.

34. Iqbal, S., Nawaz, A., \& Ehsan, S. (2019). Financial performance and corporate governance in microfinance: Evidence from Asia. Journal of Asian Economics, 60. https://doi.org/10.1016/j.asieco.2018.10.002.

35. Jacobs, K. (2005). The sacred and the secular: Examining the role of accounting in the religious context. Accounting, Auditing and Accountability Journal, 18 (2), 189-210. https://doi.org/10.1108/09513570510588724.

36. Jaelani, A. (2015). Manajemen keuangan publik di Indonesia: Tinjauan keuangan publik Islam. MPRA, 4 (1), 1-17.

37. Jaelani, A. (2016). Public Financial Management in Indonesia: Review of Islamic Public Finance. SSRN Electronic Journal, 72340. https://doi.org/10.2139/ssrn.2807095.

38. Jensen, M. C. (2005). Agency Cost Of Free Cash Flow, Corporate Finance, and Takeovers. SSRN Electronic Journal, 76 (2), 323-329. https://doi.org/10.2139/ssrn.99580

39. Jensen, M. C., \& Meckling, W. H. (1976a). Theory of the firm: Managerial behavior, agency costs and ownership structure. Journal of Financial Economics, 3 (4), 305-360. https://doi.org/10.1016/0304-405X (76)90026-X.

40. Jensen, M. C., \& Meckling, W. H. (1976b). Theory of the Firm: Managerial Behavior, Agency Costs and Ownership Structure. Journal of Financial Economics, 3, 305-360. https://doi.org/http://dx.doi.org/10.1016/0304-405X (76)90026-X.

41. Junita, A., \& Abdullah, S. (2017). Pengaruh Fiscal Stress Dan Legislature Size Terhadap Expenditure Change Pada Kabupaten/Kota Di Sumatera Utara. Jurnal Akuntansi, 20 (3), 477-478. https://doi.org/10.24912/ja.v20i3.10.

42. Kioko, S. N., Marlowe, J., Matkin, D. S. T., Moody, M., Smith, D. L., \& Zhao, Z. J. (2011). Why public financial management matters. Journal of Public Administration Research and Theory, 21 (SUPPL. 1). https://doi.org/10.1093/jopart/muq060.

43. Kristensen, J. K., Bowen, M., Long, C., \& Mustapha, S. (2019). PEFA, Public Financial Management, and Good Governance.

44. Lahiri, A. K. (2000). Sub-National Public Finance in India. Economic and Political Weekly, 35 (18), 1539-1549. https://doi.org/10.1596/978-0-8213-6927-2.

45. Langfield-Smith, K. (1997). Management control systems and strategy: A critical review. Accounting, Organizations and Society. https://doi.org/10.1016/S0361-3682 (95)00040-2

46. Larasdiputra, G. D., \& Saputra, K. A. K. (2021). Sosialisasi media online taniku " sebagai pendukung bangkitnya umkm di masa pandemi covid-19 di kelurahan kesiman, denpasar, bali. KRIDA Cendekia: Jurnal Pengabdian Masyarakat Sosialisasi, 01 (02), 7-14.

47. Larasdiputra, G. D., \& Suwitari, N. K. E. (2020). Pembinaan Pembuatan Laporan Keuangan Sederhana Usaha Mikro Kecil Dan Menengah Dan Pemahaman Kredit Usaha Rakyat. JAMAIKA: Jurnal Abdi Masyarakat, 1 (3), 133-139. http://openjournal.unpam.ac.id/index.php/JAMAIKA/article/view/6891.

48. Lawson, A. (2012). Evaluation of Public Financial Management Reform in Burkina Faso, Ghana and Malawi 2001-2010. In Final Synthesis Report 2012:7.

49. Lawson, A. (2013). Public Financial Management (Issue 6).

50. Lee, C., Cheng, C. F., Chuang, M. T., Hsu, W. C., Chen, Y. H., \& Cheng, K. T. (2018). How transparency and accountability matter in regulating the Taiwan Water Supply Corporation. Utilities Policy, 52 (521), 50-58. https://doi.org/10.1016/j.jup.2018.04.004.

51. Lengkong, V. P. ., Nelwan, O. S., \& Lumanauw, B. . (2018). Public Financial Management Kota Manado, Kota Bitung, Dan Kabupaten Minahasa Selatan. JMBI UNSRAT (Jurnal IImiah Manajemen Bisnis Dan Inovasi Universitas Sam Ratulangi)., 4 (1), 33-58. https://doi.org/10.35794/jmbi.v4i1.17404.

52. Lerner, M., Azulay, I., \& Tishler, A. (2009). The role of compensation methods in corporate entrepreneurship. International Studies of Management and Organization, 39 (3), 53-81. https://doi.org/10.2753/IMO0020-8825390303. 
53. Lin, G., \& Yi, F. (2011). Urbanization of capital or capitalization on urban land? Land development and local public finance in urbanizing China. In Urban Geography (Vol. 32, Issue 1). https://doi.org/10.2747/0272-3638.32.1.50.

54. Maestrini, V., Luzzini, D., Caniato, F., \& Ronchi, S. (2018). Effects of monitoring and incentives on supplier performance: An agency theory perspective. International Journal of Production Economics, 203 (June), 322-332. https://doi.org/10.1016/j.ijpe.2018.07.008

55. Matibini, P. (2017). Public Financial Management Handbook for Members of Parliament and Staff (Issue October).

56. Mbaku, J. M., \& Smith, J. E. (2012). the Anti-Corruption Agenda: Using Public Financial Management To Build Credible Institutions. The Brookings Institution: Africa Growth Initiative, 1 (March), 19-22.

57. Mccue, C. (2007). Local Public Financial Management. In Local Public Financial Management (Issue November 2014). https://doi.org/10.1596/978-0-8213-6937-1.

58. Mohd Noor, N. R. A., \& Mansor, N. (2019). Exploring the Adaptation of Artificial Intelligence in Whistleblowing Practice of the Internal Auditors in Malaysia. Procedia Computer Science, 163, 434-439. https://doi.org/10.1016/j.procs.2019.12.126.

59. Morgan, D., Bacon, K., Bunch, R., Cameron, C., \& Deis, R. (1996). What Middle Managers Do In Local Government: Stewardship Of The Public Trust And The Limits Of Reinventing Government. The Public Administration Review, 56 (4), 359-366.

60. Morgner, M., \& Chêne, M. (2014). Public financial mamagement tpoic guide. In Transparency International.

61. Nahar, H. S., \& Zulkeppeli, N. A. F. (2015). Questioning Public Policy's "Maintained Assumption": The Case of Governance Rules Impacting Regulatory Sanctions Among Capital Market Players in Malaysia. Procedia Economics and Finance, 31 (15), 313-324. https://doi.org/10.1016/s2212-5671 (15)01200-9.

62. Naranjo-Gil, D., \& Hartmann, F. (2007). Management accounting systems, top management team heterogeneity and strategic change. Accounting, Organizations and Society. https://doi.org/10.1016/j.aos.2006.08.003.

63. Nugraha, A. (2012). Kebijakan Seleksi Calon Pegawai Negeri Sipil Daerah (CPNSD) dalam Perspektif Sound governance. Jurnal Kebijakan Dan Manajemen PNS, 6 (1). https://jurnal.bkn.go.id/index.php/asn/article/view/99.

64. Nyamita, M. O., Dorasamy, N., \& Garbharran, H. L. (2015). A review of public sector financial management reforms: an international perspective. Public and Municipal Finance, 4 (2), 25-37. https://doi.org/10.12737/textbook_5b338ef2328875.82153292.

65. Otley, D. T. (1980). The contingency theory of management accounting: Achievement and prognosis. Accounting, Organizations and Society, 5 (4), 413-428. https://doi.org/10.1016/0361-3682 (80)90040-9.

66. Pal, L. A. (2014). Modernizing Governance. Frontiers of Governance. https://doi.org/10.1057/9780230369016.0010.

67. Park, A., Rozelle, S., Wong, C., \& Ren, C. (1996). Distributional Consequences of Reforming Local Public Finance in China. The China Quarterly, 147 (5), 751-778. https://doi.org/10.1017/s030574100005178x.

68. Pimenta, C., \& Pessoa, M. (2015). Public Financial Management in Latin America. In Public Financial Management in Latin America. https://doi.org/10.5089/9781597822268.071.

69. Porter, D., Andrews, M., Turkewitz, J. A., \& Wescott, C. G. (2011). Managing Public Finance and Procurement in Fragile and Conflicted Settings. International Public Management Journal, 14 (4), 369-394. https://doi.org/10.1080/10967494.2011.656049

70. Poterba, J. M. (1993). Global Warming Policy: A Public Finance Perspective. Journal of Economic Perspectives, 7 (4), 47-63. https://doi.org/10.1257/jep.7.4.47.

71. Raharjo, E. (2007). Agency Theory Vs Stewardship Theory in the Accounting Perspective. Fokus Ekonomi, 2 (1), 37-46.

72. Rashid, A. (2016). Managerial Ownership and Agency Cost: Evidence from Bangladesh. Journal of Business Ethics, 137 (3), 609-621. https://doi.org/10.1007/s10551-015-2570-z

73. Reverte, C. (2009). Determinants of corporate social responsibility disclosure ratings by 
Spanish listed firms. Journal of Business Ethics, 88 (2), 351-366. https://doi.org/10.1007/s10551-008-9968-9.

74. Ridla, M. R., \& Kusuma, B. M. A. (2016). Analisis Sound Governance Sebagai Upaya Meningkatkan Daya Saing Perguruan Tinggi Islam. Jurnal MD, 1 (Md 2014), 213-229.

75. Safitri, D. P., Edison, E., \& Kurnianingsih, F. (2018). Analisis Sound Governance: Sikap Pemerintah Daerah Terhadap Keterlibatan Ngo Dalam Pemberdayaan Masyarakat Pesisir. Journal of Public Administration and Local Governance, 2 (1), 1-13.

76. Safitri, D. P., Edison, \& Kurnianingsih, F. (2017). Analisis Sound Governance: Model Kemitraan Pemerintah Daerah dan Civil Society Dalam Pemberdayaan Masyarakat Pesisir. Jurnal Ilmu Administrasi Negara (JUAN), 5 (2), 35-47.

77. Saputra, K. A. K., Ekajayanti, L. G. P. S., \& Anggiriawan, P. B. (2018). Kompetensi Sumber Daya Manusia Dan Sikap Love Of Money Dalam Pengelolaan Keuangan Usaha Mikro Kecil Menengah (UMKM). Jurnal Reviu Akuntansi Dan Keuangan, 8 (2), 135-146. https://doi.org/10.22219/jrak.v8i.

78. Saputra, K. A. K., Trisnadewi, A. A. A. E., Anggiriawan, P. B., \& Kawisana, P. G. W. P. (2019). Kebangkrutan Lembaga Perkreditan Desa (Lpd) Berdasarkan Analisis Berbagai Faktor. Jurnal Ilmiah Akuntansi, 4 (1), 1-23. https://doi.org/10.23887/jia.v4i1.17250.

79. Sara, I. M., \& Saputra, K. A. K. (2021). Socialization of the implementation of good village governance and sustainability village credit institutions: Community service in Pejeng Village, Tampaksiring district, Gianyar Regency, Bali. International Journal of Business, Economics and Law, 24 (4), 58-65.

80. Sara, I. M., Saputra, K. A. K., \& Jayawarsa, A. A. K. (2020). Regulatory Impact Assessment Analysis In Traditional Village Regulations As Strengthening Culture In Bali. International Journal of Environmental, Sustainability, and Social Sciences, 1 (3), 16-23.

81. Schiavo-Campo, S. (2018). Corruption and Public Financial Management. Government Budgeting and Expenditure Management, 346-363. https://doi.org/10.4324/9781315645872-16.

82. Shaikh, A., Sector, P., Acca, N. N., Network, M., Acca, P., Sector, P., \& Financial, P. (2012). An introduction to public financial management. In Public Financial Management (Issue Parry 2010).

83. Sujana, E., Saputra, K. A. K., \& Manurung, D. T. H. (2020). Internal control systems and good village governance to achieve quality village financial reports. International Journal of Innovation, Creativity and Change, 12 (9), 98-108.

84. Sześciło, D. (2020). Public financial management. Public Administration in Central Europe: Ideas as Causes of Reforms, 196-209. https://doi.org/10.4324/978042928645216.

85. Tanzi, V. (1999). Governance, corruption, and public finance: An overview. Governance, Corruption and Public Financial Management, 1-17.

86. Taylor, R. (2003). Indigenous Community Capacity Building and the relationship to sound governance and leadership 1. National NT Conference, 1 (June), 117-118.

87. Ueshima, T. (2014). How to Assess Public Financial Management (PFM) in Developing Countries (Issue February).

88. Uğur, N. G., \& Akbıyık, A. (2020). Impacts of COVID-19 on global tourism industry: A cross-regional comparison. Tourism Management Perspectives, 36 (September), 100744. https://doi.org/10.1016/j.tmp.2020.100744.

89. Whipple, H. (2018). Value Engineering and the Lean Start-Up. 2016 Value Summit: The Power of VE.

90. William, L., Pratama, A., \& Mustamu, R. H. (2013). Penerapan Prinsip-Prinsip Good Corporate Governance Pada Perusahaan Keluarga: Studi Deskriptif Pada Distributor Makanan. Jurnal Manajemen Bisnis, 1 (1), 1-11.

91. Wiratno, A., Ningsih, W., \& Putri, N. K. (2017). Partisipasi Anggaran Terhadap Kinerja Manajerial Dengan Komitmen Organisasi, Motivasi Dan Struktur Desentralisasi Sebagai Variabel Pemoderasi. Jurnal Akuntansi, 20 (1), 150. https://doi.org/10.24912/ja.v20i1.81.

92. Yolles, M. (2019). The complexity continuum, part 2: modelling harmony. Kybernetes, 48 (8), 1626-1652. https://doi.org/10.1108/K-06-2018-0338. 